\title{
Predicting Pathogen Growth during Short-Term Temperature Abuse of Raw Pork, Beef, and Poultry Products: Use of an Isothermal-Based Predictive Tool
}

\author{
STEVEN C. INGHAM, ${ }^{1 *}$ MELODY A. FANSLAU, ${ }^{1}$ GREG M. BURNHAM, ${ }^{1}$ BARBARA H. INGHAM, ${ }^{1}$ \\ JOHN P. NORBACK, ${ }^{1}$ AND DONALD W. SCHAFFNER ${ }^{2}$ \\ ${ }^{1}$ University of Wisconsin-Madison, Madison, Wisconsin 53706; and ${ }^{2}$ Rutgers, The State University of New Jersey, \\ New Brunswick, New Jersey 08903, USA
}

MS 06-418: Received 2 August 2006/Accepted 30 January 2007

\begin{abstract}
A computer-based tool (available at: www.wisc.edu/foodsafety/meatresearch) was developed for predicting pathogen growth in raw pork, beef, and poultry meat. The tool, THERM (temperature history evaluation for raw meats), predicts the growth of pathogens in pork and beef (Escherichia coli O157:H7, Salmonella serovars, and Staphylococcus aureus) and on poultry (Salmonella serovars and $S$. aureus) during short-term temperature abuse. The model was developed as follows: 25 -g samples of raw ground pork, beef, and turkey were inoculated with a five-strain cocktail of the target pathogen(s) and held at isothermal temperatures from 10 to $43.3^{\circ} \mathrm{C}$. Log CFU per sample data were obtained for each pathogen and used to determine lag-phase duration (LPD) and growth rate (GR) by DMFit software. The LPD and GR were used to develop the THERM predictive tool, into which chronological time and temperature data for raw meat processing and storage are entered. The THERM tool then predicts a $\Delta \log$ CFU value for the desired pathogen-product combination. The accuracy of THERM was tested in 20 different inoculation experiments that involved multiple products (coarse-ground beef, skinless chicken breast meat, turkey scapula meat, and ground turkey) and temperature-abuse scenarios. With the time-temperature data from each experiment, THERM accurately predicted the pathogen growth and no growth (with growth defined as $\Delta \log C F U \geq 0.3$ ) in 67, 85, and 95\% of the experiments with E. coli O157:H7, Salmonella serovars, and S. aureus, respectively, and yielded failsafe predictions in the remaining experiments. We conclude that THERM is a useful tool for qualitatively predicting pathogen behavior (growth and no growth) in raw meats. Potential applications include evaluating process deviations and critical limits under the HACCP (hazard analysis critical control point) system.
\end{abstract}

Since 2000, all wholesale meat processors in the United States have been required to use the hazard analysis critical control point (HACCP) system for ensuring food safety (16). Under the HACCP system, processors must conduct a hazard analysis for each of their products and then develop and implement an HACCP plan for the control of identified hazards that are reasonably likely to occur. The HACCP plan specifically deals with identified process steps-critical control points (CCPs) - that must be properly executed to control these hazards. A CCP is defined as "a point, step, or procedure in a food process at which control can be applied and, as a result, a food safety hazard can be prevented, eliminated, or reduced to acceptable levels" (16). Scientifically validated critical limits must then be specified as criteria for use in monitoring each identified CCP.

In a typical hazard analysis for a raw pork, beef, or poultry product, the growth of pathogens such as Escherichia coli O157:H7, Salmonella serovars, and Staphylococcus aureus will be identified as a hazard that is reasonably likely to occur. These pathogens cannot be eliminated during the typical processing of raw products, but their

\footnotetext{
* Author for correspondence. Tel: 608-265-4801; Fax: 608-262-6872; E-mail: scingham@wisc.edu.
}

growth can be controlled by at least one CCP, typically the step at which the product temperature is the warmest. Presently, to our knowledge, there is no U.S. Department of Agriculture (USDA) guideline that provides previously accepted critical limits for this type of CCP in pork and beef processing, although $13^{\circ} \mathrm{C}$ is the regulatory limit for raw poultry product temperatures during processing (19). In many small and very small meat plants with unrefrigerated raw meat processing areas, the temperature at the processing step designated the CCP may be high enough that the product can be considered to have undergone short-term temperature abuse. Furthermore, some processing steps, such as grinding, can cause an increase in raw meat temperature. Raw products may also be exposed to short-term temperature abuse during CCP deviations or other processing or scheduling problems. Clearly, scientifically valid information is needed to set time limits for preventing pathogen growth when raw meat products are held for short times at abusive temperatures.

Ideally, processors would obtain scientifically valid information through controlled inoculation studies. However, this approach is not safe, practical, or affordable for most processors. Alternatively, laboratory-based studies of pathogen growth on actual products can be conducted. This approach has been followed in a variety of situations $(4,5$, 
TABLE 1. Chemical and physical characteristics of typical laboratory-ground pork, beef, and turkey used to develop THERM and commercial coarse-ground beef, skinless chicken breast meat, turkey scapula meat, and ground turkey used in experiments to test THERM

\begin{tabular}{|c|c|c|c|c|c|c|c|c|}
\hline \multirow[b]{2}{*}{ Analysis } & \multirow{2}{*}{$\begin{array}{l}\text { Laboratory- } \\
\text { ground pork }\end{array}$} & \multirow{2}{*}{$\begin{array}{l}\text { Laboratory- } \\
\text { ground beef }\end{array}$} & \multirow{2}{*}{$\begin{array}{c}\text { Coarse-ground } \\
\text { beef }\end{array}$} & \multirow{2}{*}{$\begin{array}{l}\text { Laboratory- } \\
\text { ground turkey }\end{array}$} & \multirow{2}{*}{$\begin{array}{l}\text { Skinless } \\
\text { chicken } \\
\text { breasts }\end{array}$} & \multirow{2}{*}{$\begin{array}{c}\text { Turkey } \\
\text { scapula meat }\end{array}$} & \multicolumn{2}{|c|}{ Commercial ground turkey } \\
\hline & & & & & & & Plant A & Plant $\mathrm{B}^{a}$ \\
\hline $\mathrm{pH}$ & 5.7 & 5.7 & 5.4 & 5.9 & 5.8 & 5.8 & 5.8 & 6.1 \\
\hline$\%$ moisture & 73.9 & 73.2 & 62.4 & 73.7 & 72.9 & 73.5 & 70.9 & 69.7 \\
\hline$\%$ fat & 1.7 & 4.0 & 18.2 & 1.0 & 1.3 & 3.2 & 9.6 & 12.6 \\
\hline$\%$ protein & 23.6 & 22.1 & 17.6 & 24.0 & 24.4 & 22.5 & 18.2 & 17.2 \\
\hline$\%$ salt & $<0.05$ & 0.06 & 0.14 & 0.09 & 0.09 & 0.08 & 0.1 & 0.3 \\
\hline
\end{tabular}

$a$ The product contained added rosemary extract preservatives.

7, 8). Another possible way to generate the needed information is to analyze the processing time-temperature conditions by computer-generated predictive models of pathogen growth. For example, pathogen growth during nonisothermal temperature abuse could be predicted by dividing the product time-temperature history into multiple small temperature-change intervals and then applying the USDA Pathogen Modeling Program (PMP 7.0, Agricultural Research Service, Eastern Regional Research Center, Wyndmoor, Pa.) to predict the pathogen growth in each interval. The estimated pathogen growth would be the sum of the predicted growth for each interval. However, because many of the PMP 7.0 models are derived from studies with pure pathogen cultures in laboratory media, USDA regulators have not generally accepted this approach as the sole means of scientific validation (20). In contrast, the Agricultural Research Service, Eastern Regional Research Center, has developed a tool for predicting E. coli O157:H7 growth that is based on experiments with sterile ground beef (14). This tool, although based on studies with meat, does not account for potential growth-affecting interactions between $E$. coli O157:H7 and nonpathogenic bacteria indigenous to commercial products.

A more versatile, low-cost alternative to pathogen challenge studies and existing predictive tools is the development of a computer-generated predictive tool based on pathogen growth data obtained from multiple inoculation studies conducted with nonsterile, raw ground pork, beef, and poultry. By this approach, the growth predictions would be based on the observed behavior of relatively high numbers of pathogen cells, in the absence of added inhibitory substances such as sodium chloride or sodium nitrite, and with a low, but realistic, level of competing microorganisms, i.e., a simulated "worst-case" situation. In an earlier study, we presented such a tool and validated its use for predicting the growth of E. coli O157:H7, Salmonella serovars, and $S$. aureus during the slow partial-cooking of bacon (1). In the present study, we developed a tool, THERM (temperature history evaluation for raw meats), for predicting pathogen growth in raw pork and beef (E. coli O157:H7, Salmonella serovars, and S. aureus) and on poultry meat (Salmonella serovars and S. aureus) during shortterm temperature-abuse situations. We tested the accuracy of THERM by subjecting inoculated, raw coarse-ground beef; raw, skinless chicken breast meat; raw turkey scapula meat; and raw ground turkey to short-term temperatureabuse situations and comparing the experimentally determined pathogen growth with the level of pathogen growth predicted by THERM.

\section{MATERIALS AND METHODS}

Raw ground pork, beef, and turkey used in developing THERM. Fresh, vacuum-packaged, nonenhanced (not injected with phosphate solution) pork loins were obtained from a local retail store or directly from a local wholesale distributor. Fresh, vacuum-packaged beef roasts were obtained from a local retail store. A large box of frozen, nonenhanced, skinless turkey breasts was obtained from a local wholesale distributor. Pork loins were frozen at $-20^{\circ} \mathrm{C}$ and then thawed at $5^{\circ} \mathrm{C}$ before grinding, while beef roasts were ground within 1 day of arrival at the laboratory. Before grinding, fat was trimmed from the pork loins and beef roasts, because high fat content may slow the growth rate (GR) of E. coli $\mathrm{O} 157: \mathrm{H} 7$ in raw meats (13). Turkey breasts were stored in the freezer $\left(-20^{\circ} \mathrm{C}\right)$ and then thawed at $5^{\circ} \mathrm{C}$ in preparation for grinding. Meat was ground once with a meat grinder (a grinding plate with 4-mm-diameter holes; Univex model MG8912, Univex, Salem, N.H.).

Raw meat microbiological and chemical analyses. A 25-g sample of ground meat from each purchased package or box was placed in a filter bag measuring 15.25 by $23 \mathrm{~cm}$ ( 6 by 9 in.) and diluted with $99 \mathrm{ml}$ of Butterfield's phosphate diluent (BPD; Nelson Jameson, Marshfield, Wis.). The sample was then appropriately diluted in BPD and plated on $3 \mathrm{M}$ Petrifilm aerobic count plates (APC; 3M Microbiology, St. Paul, Minn.) and incubated at $35^{\circ} \mathrm{C}$ for $48 \mathrm{~h}$ to determine the concentration of indigenous bacteria (APC) in the meat product before its use in isothermal studies. One sample each of a representative lot of ground pork, ground beef, and ground turkey was sent to a commercial laboratory for a determination of the $\mathrm{pH}$, percent moisture, percent fat, percent protein, and percent salt (Table 1). Other than the samples for APC determination and chemical analyses, the ground meats were vacuum sealed in large plastic bags and frozen at $-20^{\circ} \mathrm{C}$ until thawing at $5^{\circ} \mathrm{C}$ before use.

Preparation of inocula. Five strains each of E. coli O157: H7, Salmonella serovars, and $S$. aureus were used in developing and testing THERM (Table 2). Each strain was prepared from a frozen stock culture, with a working culture plate prepared by successively culturing twice at $35^{\circ} \mathrm{C}$ for 18 to $24 \mathrm{~h}$ in brain heart infusion broth (Difco, Becton Dickinson, Sparks, Md.), streaking to brain heart infusion agar (Difco, Becton Dickinson), incubating at $35^{\circ} \mathrm{C}$ for 18 to $24 \mathrm{~h}$, examining for homogeneous colony morphology, and then storing the plate at $5^{\circ} \mathrm{C}$. An isolated colony of 
TABLE 2. Pathogen strains used for the development and testing of THERM

\begin{tabular}{|c|c|c|c|}
\hline Species & Strain no. & $\begin{array}{l}\text { Source of } \\
\text { isolation }\end{array}$ & $\begin{array}{l}\text { Source of } \\
\text { strain }^{a}\end{array}$ \\
\hline $\begin{array}{l}\text { Escherichia coli } \\
\text { O157:H7 }\end{array}$ & $\begin{array}{l}\text { USDA-FSIS }^{b} \\
380-94\end{array}$ & $\begin{array}{l}\text { Salami implicat- } \\
\text { ed in illness } \\
\text { outbreak }\end{array}$ & 1 \\
\hline E. coli $\mathrm{O} 157: \mathrm{H} 7$ & ATCC 43894 & Clinical sample & 2 \\
\hline E. coli $\mathrm{O} 157: \mathrm{H} 7$ & ATCC 43895 & $\begin{array}{l}\text { Ground beef im- } \\
\text { plicated in ill- } \\
\text { ness outbreak }\end{array}$ & 2 \\
\hline E. coli $\mathrm{O} 157: \mathrm{H} 7$ & ATCC 51657 & Clinical sample & 2 \\
\hline E. coli $\mathrm{O} 157: \mathrm{H} 7$ & ATCC 51658 & Clinical sample & 2 \\
\hline $\begin{array}{l}\text { Salmonella Ty- } \\
\text { phimurium }\end{array}$ & S9 & $\begin{array}{l}\text { Clinical sample, } \\
\text { Wisconsin } \\
\text { Laboratory of } \\
\text { Hygiene }\end{array}$ & 3 \\
\hline $\begin{array}{l}\text { Salmonella Hei- } \\
\text { delberg }\end{array}$ & $\mathrm{S} 13$ & $\begin{array}{l}\text { Clinical sample, } \\
\text { Wisconsin } \\
\text { Laboratory of } \\
\text { Hygiene }\end{array}$ & 3 \\
\hline $\begin{array}{l}\text { Salmonella In- } \\
\text { fantis }\end{array}$ & S20 & Unknown & 3 \\
\hline $\begin{array}{l}\text { Salmonella Had- } \\
\text { ar }\end{array}$ & $\mathrm{S} 21$ & Unknown & 3 \\
\hline $\begin{array}{l}\text { Salmonella En- } \\
\text { teritidis }\end{array}$ & $\mathrm{E} 40$ & $\begin{array}{l}\text { Chicken ovary } \\
\text { isolate, New } \\
\text { York Depart- } \\
\text { ment of Health }\end{array}$ & 3 \\
\hline $\begin{array}{l}\text { Staphylococcus } \\
\text { aureus }\end{array}$ & ATCC 12600 & Clinical sample & 2 \\
\hline S. aureus & ATCC 25923 & Clinical sample & 2 \\
\hline S. aureus & FRI-100 & $\begin{array}{l}\text { Cake implicated } \\
\text { in illness out- } \\
\text { break }\end{array}$ & 4 \\
\hline S. aureus & FRI-472 & $\begin{array}{l}\text { Turkey salad im- } \\
\text { plicated in ill- } \\
\text { ness outbreak }\end{array}$ & 4 \\
\hline S. aureus & FRI-1007 & $\begin{array}{l}\text { Genoa salami } \\
\text { implicated in } \\
\text { illness out- } \\
\text { break }\end{array}$ & 4 \\
\hline
\end{tabular}

a 1, Dr. John Luchansky, formerly Food Research Institute, University of Wisconsin-Madison; now at USDA, Agricultural Research Service, Eastern Regional Research Center; 2, American Type Culture Collection, Manassas, Va.; 3, Dr. Eric Johnson, Food Research Institute, University of Wisconsin-Madison; 4, Dr. Amy Wong, Food Research Institute, University of Wisconsin-Madison.

${ }^{b}$ FSIS, Food Safety and Inspection Service.

each strain was transferred from its working culture plate to $9 \mathrm{ml}$ of brain heart infusion broth and then incubated at $35^{\circ} \mathrm{C}$ for $24 \mathrm{~h}$. Inocula were prepared for each pathogen by combining each of the five cultured strains into a 50-ml centrifuge tube and centrifuging at $5,000 \times g$ for $12 \mathrm{~min}$. Because earlier studies in our laboratory had shown that combining all three pathogen species significantly inhibited the growth of $S$. aureus in inoculated raw meat (data not shown), two different inocula were prepared for the pork and beef experiments. The first contained E. coli O157: H7 and Salmonella serovars prepared as follows: the supernatant was decanted from each five-strain mixture, and each pellet was resuspended to $25 \mathrm{ml}$ with $\mathrm{BPD}$. From both five-strain mixtures, $10 \mathrm{ml}$ was transferred to another 50-ml centrifuge tube, creating $20 \mathrm{ml}$ of a 10-strain, two-pathogen inoculum containing ca. 9 log $\mathrm{CFU} / \mathrm{ml}$. The second inoculum, containing only $S$. aureus at a level of ca. $9 \log \mathrm{CFU} / \mathrm{ml}$, was prepared by decanting the supernatant from the five-strain mixture and resuspending the pellet to $45 \mathrm{ml}$ with BPD. Finally, each inoculum was diluted 100-fold in BPD. For experiments with turkey, the same procedure was followed, except that E. coli O157:H7 was not used.

Preparation and inoculation of meat. Isothermal studies were conducted at approximately $2.8^{\circ} \mathrm{C}$ intervals (actually measured as $5^{\circ} \mathrm{F}$, because the U.S. meat industry uses the Fahrenheit scale) ranging from 10 to $43.3^{\circ} \mathrm{C}\left(50\right.$ to $\left.110^{\circ} \mathrm{F}\right)$. Raw ground pork, beef, and turkey (ca. $25 \mathrm{~g}$ ) were weighed out into sample bags $(7.5$ by $18.5 \mathrm{~cm}$ ) and allowed to reach the test temperature either in a static water bath (temperatures above room temperature [RT]) or an incubator (temperatures at, or below, RT). A type K thermocouple, attached to a model SP150 data logger (Dickson, Addison, Ill.), was inserted in the center of a bag of meat to determine when the test temperature had been reached. When the test temperature was reached, each meat sample (except for the one containing the thermocouple) was inoculated with $100 \mu \mathrm{l}$ of (i) the E. coli O157:H7 and Salmonella serovars inoculum (beef and pork), (ii) the Salmonella serovars inoculum (turkey), or (iii) the S. aureus inoculum (all products). Previously, we determined that pathogen growth was faster when the inoculum was dispersed in the ground meat than when it was localized in a "hole" within the meat mass (data not shown); hence, each inoculated sample bag was sealed and manually massaged for $20 \mathrm{~s}$ to distribute the inoculum throughout the meat mass. Bags of inoculated product were returned to the isothermal experiment temperature as quickly as possible $(<5 \mathrm{~min})$. Three concurrent trials were conducted for each temperature, with separate inocula prepared for each trial, and enough bags of inoculated product were prepared to allow an analysis of one bag for each inoculum type in each trial at every sampling time.

Enumeration of inoculum organisms. In experiments to develop THERM, three bags per inoculum type (one per trial) were removed at each sampling time from the water bath or incubator. The outer surface of each bag was sanitized with $70 \%$ ethanol and allowed to dry. Once dry, the contents of each bag were transferred to a filter bag measuring 15.25 by $23 \mathrm{~cm}$. The original sample bag was everted to expose any inoculum still on the bag and was also placed into the filter bag. The ground meat sample and original sample bag were combined with $99 \mathrm{ml}$ of BPD, stomached at normal speed for $30 \mathrm{~s}$ with a stomacher laboratory blender (Fisher Scientific, Itasca, Ill.), and serially diluted (in BPD). Similar sampling and initial sample homogenization were done at each sampling time in experiments to test THERM (see below). For each dilution, $100 \mu \mathrm{l}$ was spread on a single plate with a sterile, bent, plastic spreader. The selective medium used for $E$. coli O157:H7 was sorbitol MacConkey agar (Difco, Becton Dickinson) on which typical colonies are colorless to white and opaque. The selective medium used for the Salmonella serovars was xylose lysine decarboxylase agar (Oxoid, Ogdensburg, N.Y.) on which typical colonies have a black center and a well-defined clear-to-opaque halo. The selective medium used for $S$. aureus was Baird-Parker agar base (Difco, Becton Dickinson) with a tellurite egg yolk supplement (Difco, Becton Dickinson). Typical $S$. aureus colonies on Baird-Parker agar base are shiny black with a distinctive clear zone in the surrounding agar. The sorbitol MacConkey agar and xylose lysine decarboxylase plates were incubated at $35^{\circ} \mathrm{C}$ for $24 \mathrm{~h}$, and the Baird-Parker agar plates were 
TABLE 3. Ground pork: observed lag-phase duration (LPD), growth rate (GR), and $\mathrm{R}^{2}$ values (derived by DMFit) for E. coli O157: $H 7(E C)$, Salmonella serovars $(S A L M)$, and $\mathrm{S}$. aureus $(S A)^{a}$

\begin{tabular}{|c|c|c|c|c|c|c|c|c|c|}
\hline \multirow[b]{2}{*}{$\begin{array}{l}\text { Temp } \\
\left({ }^{\circ} \mathrm{C} /{ }^{\circ} \mathrm{F}\right)\end{array}$} & \multicolumn{3}{|c|}{$\mathrm{EC}$} & \multicolumn{3}{|c|}{ SALM } & \multicolumn{3}{|c|}{ SA } \\
\hline & $\begin{array}{l}\text { LPD } \\
(\min )\end{array}$ & $\begin{array}{c}\text { GR } \\
(\log \mathrm{CFU} / \mathrm{min})\end{array}$ & $R^{2}$ & $\begin{array}{l}\text { LPD } \\
(\min )\end{array}$ & $\begin{array}{c}\text { GR } \\
(\log \mathrm{CFU} / \mathrm{min})\end{array}$ & $R^{2}$ & $\begin{array}{l}\text { LPD } \\
(\min )\end{array}$ & $\begin{array}{c}\text { GR } \\
(\log \mathrm{CFU} / \mathrm{min})\end{array}$ & $R^{2}$ \\
\hline $43.3 / 110$ & 44 & 0.0133 & 0.97 & 74 & 0.0146 & 0.98 & 149 & 0.0177 & 0.98 \\
\hline $40.6 / 105$ & 59 & 0.0186 & 0.99 & 74 & 0.0153 & 0.96 & 124 & 0.0179 & 0.95 \\
\hline $37.8 / 100$ & 51 & 0.0136 & 0.98 & 93 & 0.0146 & 0.97 & 110 & 0.0121 & 0.98 \\
\hline $35.0 / 95$ & 60 & 0.0146 & 0.95 & 100 & 0.0089 & 0.73 & 140 & 0.0120 & 0.97 \\
\hline $32.2 / 90$ & 103 & 0.0067 & 0.93 & 154 & 0.0118 & 0.76 & 207 & 0.0134 & 0.97 \\
\hline $29.5 / 85$ & 89 & 0.0077 & 0.94 & 106 & 0.0076 & 0.92 & 214 & 0.0059 & 0.96 \\
\hline $26.7 / 80$ & 128 & 0.0052 & 0.83 & 261 & 0.0110 & 0.84 & 312 & 0.0046 & 0.98 \\
\hline $23.9 / 75$ & 154 & 0.0048 & 0.91 & 257 & 0.0072 & 0.88 & 330 & 0.0028 & 0.84 \\
\hline $21.1 / 70$ & 139 & 0.0027 & 0.93 & 343 & 0.0058 & 0.90 & 375 & 0.0024 & 0.96 \\
\hline $18.4 / 65$ & 315 & 0.0031 & 0.92 & 490 & 0.0059 & 0.94 & 1,275 & 0.0028 & 0.87 \\
\hline $15.6 / 60$ & 360 & 0.0019 & 0.95 & 528 & 0.0020 & 0.94 & 1,235 & 0.0008 & 0.96 \\
\hline $12.8 / 55$ & 1,061 & 0.0011 & 0.96 & 1,030 & 0.0012 & 0.91 & $\mathrm{NG}^{b}$ & NG & \\
\hline $10.0 / 50$ & 2,286 & 0.0004 & 0.98 & 3,282 & 0.00048 & 0.84 & NG & NG & \\
\hline
\end{tabular}

${ }^{a}$ Indigenous microbial load before inoculation was $\leq 3.5 \mathrm{log} \mathrm{CFU} / \mathrm{g}$.

${ }^{b} \mathrm{NG}$, no growth.

incubated at $35^{\circ} \mathrm{C}$ for $48 \mathrm{~h}$. After colony enumeration, one typical colony of each pathogen per test temperature was transferred to brain heart infusion agar and grown overnight at $35^{\circ} \mathrm{C}$ for confirmation. Gram staining reaction, cell morphology, and colony morphology were observed for all isolates. A latex agglutination test (Oxoid) was also done for presumptive $S$. aureus. For presumptive Salmonella serovars, the oxidase test (DrySlide kit, Fisher) and API 20E biochemical characterization (bioMérieux, Hazelwood, Mo.) were also done, and an oxidase test and latex agglutination test (Oxoid) were used to confirm presumptive colonies of $E$. coli O157:H7.

The THERM tool. For each pathogen and test temperature, the log CFU per sample was determined at each sampling time for each of the three trials. The sampling time and log CFU per sample data were then entered for each pathogen and test tem- perature into the DMFit 1.0 program (J. Baranyi, Institute of Food Research, Norwich Research Park, Norwich, UK), which generated a best-fit growth curve, with an estimated lag-phase duration (LPD), GR, and corresponding $R^{2}$ value (Tables 3 through 5). The LPD and GR values for each combination of pathogen and type of raw meat were used to develop the THERM tool. Software has been written that allows the user to enter up to 20 elapsed-time (expressed in minutes) and temperature (expressed in degrees Fahrenheit) data pairs. This software uses an interval accumulation strategy to estimate the percentage of LPD that elapses in each time interval (constant temperature assumed) by dividing the interval time by the LPD and multiplying the resulting value by 100. The percentage of LPD contributed by each interval is accumulated and displayed interval by interval until $100 \%$ of the time in lag phase has elapsed (equation 1).

TABLE 4. Ground beef: observed lag-phase duration (LPD), growth rate $(G R)$, and $\mathrm{R}^{2}$ values (derived by DMFit) for E. coli O157: $H 7(E C)$, Salmonella serovars $(S A L M)$, and $\mathrm{S}$. aureus $(S A)^{a}$

\begin{tabular}{|c|c|c|c|c|c|c|c|c|c|}
\hline \multirow[b]{2}{*}{$\begin{array}{l}\text { Temp } \\
\left({ }^{\circ} \mathrm{C} /{ }^{\circ} \mathrm{F}\right)\end{array}$} & \multicolumn{3}{|c|}{$\mathrm{EC}$} & \multicolumn{3}{|c|}{ SALM } & \multicolumn{3}{|c|}{ SA } \\
\hline & $\begin{array}{l}\text { LPD } \\
(\min )\end{array}$ & $\begin{array}{c}\mathrm{GR} \\
(\log \mathrm{CFU} / \mathrm{min})\end{array}$ & $R^{2}$ & $\begin{array}{l}\text { LPD } \\
(\min )\end{array}$ & $\begin{array}{c}\text { GR } \\
(\log \mathrm{CFU} / \mathrm{min})\end{array}$ & $R^{2}$ & $\begin{array}{l}\text { LPD } \\
(\min )\end{array}$ & $\begin{array}{c}\text { GR } \\
(\log \mathrm{CFU} / \mathrm{min})\end{array}$ & $R^{2}$ \\
\hline $43.3 / 110$ & 63 & 0.0262 & 0.89 & 79 & 0.0146 & 0.90 & 111 & 0.0107 & 0.99 \\
\hline $40.6 / 105$ & 63 & 0.0169 & 0.95 & 105 & 0.0219 & 0.92 & 102 & 0.0111 & 0.9 \\
\hline $37.8 / 100$ & 86 & 0.0201 & 0.70 & 106 & 0.0195 & 0.97 & 101 & 0.0129 & 0.99 \\
\hline $35.0 / 95$ & 78 & 0.0147 & 0.91 & 90 & 0.0109 & 0.94 & 155 & 0.0111 & 0.99 \\
\hline $32.2 / 90$ & 86 & 0.0100 & 0.98 & 105 & 0.0086 & 0.91 & 149 & 0.0078 & 0.99 \\
\hline $29.5 / 85$ & 99 & 0.0060 & 0.91 & 107 & 0.0057 & 0.90 & 192 & 0.0069 & 0.97 \\
\hline $26.7 / 80$ & 130 & 0.0062 & 0.95 & 123 & 0.0060 & 0.96 & 346 & 0.0057 & 0.99 \\
\hline $23.9 / 75$ & 156 & 0.0028 & 0.90 & 180 & 0.0030 & 0.86 & 260 & 0.0032 & 0.99 \\
\hline $21.1 / 70$ & 216 & 0.0034 & 0.77 & 215 & 0.0039 & 0.95 & 361 & 0.0024 & 0.79 \\
\hline $18.4 / 65$ & 251 & 0.0028 & 0.99 & 232 & 0.0032 & 0.99 & 751 & 0.0011 & 0.94 \\
\hline $15.6 / 60$ & 387 & 0.0015 & 0.95 & 513 & 0.0016 & 0.90 & $\mathrm{NG}^{b}$ & NG & NG \\
\hline $12.8 / 55$ & 560 & 0.0012 & 0.99 & 747 & 0.0012 & 0.99 & $\mathrm{NG}$ & NG & NG \\
\hline $10.0 / 50$ & 1,625 & 0.0004 & 0.74 & 2,784 & 0.0002 & 0.82 & NG & NG & NG \\
\hline
\end{tabular}

${ }^{a}$ Indigenous microbial load before inoculation was $\leq 3.5 \log \mathrm{CFU} / \mathrm{g}$.

${ }^{b} \mathrm{NG}$, no growth. 
TABLE 5. Ground turkey: observed lag-phase duration (LPD), growth rate $(G R)$, and $\mathrm{R}^{2}$ values (derived by DMFit) for Salmonella serovars $(S A L M)$ and $\mathrm{S}$. aureus $(S A)^{a}$

\begin{tabular}{lrrrrrrr}
\hline & \multicolumn{3}{c}{ SALM } & & \multicolumn{3}{c}{ SA } \\
\cline { 2 - 5 } \cline { 6 - 8 } $\begin{array}{c}\text { Temp } \\
\left({ }^{\circ} \mathrm{C} /{ }^{\circ} \mathrm{F}\right)\end{array}$ & $\begin{array}{c}\text { LPD } \\
(\mathrm{min})\end{array}$ & $\begin{array}{c}\text { GR }(\log \\
\text { CFU/min })\end{array}$ & $R^{2}$ & & $\begin{array}{c}\text { LPD } \\
(\mathrm{min})\end{array}$ & $\begin{array}{c}\text { GR (log } \\
\text { CFU/min })\end{array}$ & $R^{2}$ \\
\hline $43.3 / 110$ & 44 & 0.0110 & 0.81 & & 134 & 0.009 & 0.97 \\
$40.6 / 105$ & 48 & 0.0156 & 0.99 & & 57 & 0.0060 & 0.93 \\
$37.8 / 100$ & 92 & 0.0162 & 0.98 & & 156 & 0.0161 & 0.99 \\
$35.0 / 95$ & 137 & 0.0171 & 0.88 & & 158 & 0.0120 & 0.99 \\
$32.2 / 90$ & 134 & 0.0085 & 0.80 & & 130 & 0.0096 & 0.98 \\
$29.5 / 85$ & 136 & 0.0117 & 0.86 & & 208 & 0.0066 & 0.77 \\
$26.7 / 80$ & 207 & 0.0106 & 0.86 & & 249 & 0.0055 & 0.98 \\
$23.9 / 75$ & 186 & 0.0056 & 0.96 & & 232 & 0.0033 & 0.97 \\
$21.1 / 70$ & 281 & 0.0029 & 0.80 & & 498 & 0.0021 & 0.96 \\
$18.4 / 65$ & 501 & 0.0028 & 0.94 & & 1,217 & 0.0037 & 0.98 \\
$15.6 / 60$ & 826 & 0.0022 & 0.73 & & 966 & 0.0009 & 0.97 \\
$12.8 / 55$ & 887 & 0.0008 & 0.96 & & NG ${ }^{b}$ & NG & NG \\
$10.0 / 50$ & 1,364 & 0.0004 & 0.84 & & NG & NG & NG \\
\hline
\end{tabular}

${ }^{a}$ Indigenous microbial load before inoculation was $\leq 3.5 \log$ $\mathrm{CFU} / \mathrm{g}$.

${ }^{b} \mathrm{NG}$, no growth.

$$
\text { total \% LPD }=\sum_{i=1}^{N} \text { interval time } / \mathrm{LPD}_{i} \times 100
$$

After the lag phase is complete, interval accumulation is used to estimate the subsequent growth, expressed in log CFU. The log CFU of growth is computed by multiplying the GR (log CFU per minute) by either the time (in minutes) remaining in the interval during which the lag phase ended or the total time of the interval (for all intervals thereafter; equation 2).

$$
\text { total growth }=\sum_{i=1}^{N} \text { GR for interval }{ }_{i} \times \text { interval time }_{i}
$$

Temperature was assumed to be constant throughout each interval. When temperature values entered by the user do not coincide with experimental temperatures used $\left(2.8^{\circ} \mathrm{C}\right.$ intervals from 10 to $43.3^{\circ} \mathrm{C}$ ), linear interpolation is performed between DMFit-derived LPD and GR values to obtain the LPD and GR values for use in calculating the predicted growth.

Testing THERM performance in commercial product inoculation studies. The accuracy of THERM was tested in several inoculation studies with coarse-ground beef, pieces of skinless chicken breast meat and turkey scapula meat, and ground turkey meat. These products were inoculated, subjected to various shortterm temperature-abuse regimes, and analyzed to determine pathogen populations at predetermined time points during the temperature abuse. A time-temperature history for either the product (4.5-kg chubs [vacuum-sealed cylindrical packages] of coarseground beef) or the storage environment (poultry products) was also obtained in each experiment to enter into THERM and obtain a predicted change in log CFU, or $\Delta \log \mathrm{CFU}$.

Coarse-ground beef in $4.5-\mathrm{kg}$ chubs was obtained from a local wholesale distributor. A representative sample was sent to a commercial laboratory for chemical and physical analysis (Table 1). At the time of use, the concentration of indigenous bacteria (APC) was quantified as described earlier. Inocula for coarseground beef studies were prepared as described previously. To inoculate the $4.5-\mathrm{kg}$ chubs, twelve $25 \mathrm{-g}$ samples were removed from 12 squares measuring 3.8 by $3.8 \mathrm{~cm}$ made by cutting incisions through the packaging material on the top half of the long axis of the chub. The 25-g samples were placed in small (7.5 by $18.5 \mathrm{~cm}$ ), sampling bags inoculated with $100 \mu$ of either the $E$. coli 0157:H7 and Salmonella serovars inoculum or the $S$. aureus inoculum, and manually massaged for $20 \mathrm{~s}$ to disperse the inoculum. The inoculated samples in sample bags were flattened to attain the original dimensions $(3.8$ by $3.8 \mathrm{~cm}$ ) and placed back into the incisions $(3.8$ by $3.8 \mathrm{~cm}$ ) made in the chubs, with the ends of the sample bags inserted just underneath the packaging of the product. After inoculation, the surface of each $4.5-\mathrm{kg}$ coarse-ground beef chub contained six samples inoculated with $E$. coli O157:H7 and Salmonella serovars and six samples inoculated with $S$. aureus.

Inoculated coarse-ground beef chubs were subjected to one of three temperature-abuse situations (Table 6). For each coarseground beef experiment, a temperature probe attached to a data logger was inserted just under the surface in the center of the chub to record the time-temperature data, which were then entered into THERM. Data points were selected by dividing the experiment time into 20 equal intervals and determining the temperature at each of the times from the data logger output. In coarse-ground beef experiments, the three temperature-abuse situations represented (i) pathogen contamination of refrigerated raw meat, followed by short-term holding ( 3 to $6 \mathrm{~h}$ ) at RT or $35^{\circ} \mathrm{C}$ (experiments 1 to 4 ); (ii) thawing of previously contaminated and frozen products at RT or $35^{\circ} \mathrm{C}$ (12 to $15 \mathrm{~h}$; experiments 5 to 8 ); and (iii) holding of meat that had been previously contaminated, frozen, and thawed at RT or $35^{\circ} \mathrm{C}$ for $12 \mathrm{~h}$ (experiments 9 to 12). Sampling (one sample bag per inoculum) and pathogen enumeration were done as described earlier at predetermined times throughout each experiment. Frozen or frozen-thawed samples were spread plated on nutrient agar (Difco, Becton Dickinson) and incubated at $35^{\circ} \mathrm{C}$ for $1 \mathrm{~h}$ to encourage repair of freeze-thaw-induced injury, and then the nutrient agar was overlaid with the appropriate selective medium (tempered at $48^{\circ} \mathrm{C}$ ). Incubation then continued at $35^{\circ} \mathrm{C}$ for the usual $24-$ or 48 -h period.

Fresh, skinless chicken breasts and ground turkey meat from two different processors were obtained at a local retail store and either stored at $5^{\circ} \mathrm{C}$ or frozen and then thawed at $5^{\circ} \mathrm{C}$ before use, respectively. Frozen turkey scapula meat was obtained from a local wholesale distributor, stored frozen, and then thawed at $5^{\circ} \mathrm{C}$ before use. A representative sample of each product was sent to a commercial laboratory for chemical and physical analysis (Table 1). The APC was determined for each product as described earlier. Each type of poultry product was subdivided into small portions, inoculated with either the Salmonella serovars or the $S$. aureus (inoculum prepared as described previously), and then stored. Storage treatments were either at $13^{\circ} \mathrm{C}$ for $8 \mathrm{~h}$ (experiments 13 to 16), mimicking a processing environment barely complying with USDA regulations (19), or sequentially at $13^{\circ} \mathrm{C}$ for $3 \mathrm{~h}, 21^{\circ} \mathrm{C}$ for $3 \mathrm{~h}$, and $30^{\circ} \mathrm{C}$ for $4 \mathrm{~h}$ (experiments 17 to 20 ). The latter experiments mimicked an extreme loss of temperature control (e.g., products inadvertently left on a loading dock, cooler failure). Small pieces of meat 2.5 by 2.5 by $1.8 \mathrm{~cm}$ thick were excised from the surface of the skinless chicken breasts and from the turkey scapula meat, and $100 \mu \mathrm{l}$ of either the Salmonella serovars or the $S$. aureus inoculum was pipetted onto the surface of each piece and distributed with a sterile plastic spreader. Each inoculated piece was placed in a sample bag $(7.5$ by $18.5 \mathrm{~cm})$. Ground turkey meat was distributed in sample bags $(7.5$ by $18.5 \mathrm{~cm} ; 25$ $\mathrm{g}$ per bag) and inoculated with either the Salmonella serovars or the $S$. aureus as described earlier. A bag of each product for each inoculum type was analyzed to obtain time zero inoculum levels, and all remaining bags were then stored. A thermocouple and data logger, as described earlier, were used to monitor storage temper- 
TABLE 6. Outline of temperature-abuse experiments with inoculated coarse-ground beef (GB), skinless chicken breasts $(C)$, turkey scapula meat $(T)$, ground turkey meat from plant A (GT-A), and ground turkey meat from plant $B(G T-B)$

\begin{tabular}{cccc}
\hline Expt no. & Product & Storage temp $\left({ }^{\circ} \mathrm{C}\right)$ & Holding time \\
\hline 1 & GB & $\mathrm{RT}^{a}$ & $340 \mathrm{~min}^{b}$ \\
2 & GB & $\mathrm{RT}$ & $360 \mathrm{~min}^{b}$ \\
3 & $\mathrm{~GB}$ & 35 & $180 \mathrm{~min}^{b}$ \\
4 & $\mathrm{~GB}$ & 35 & $240 \mathrm{~min}^{b}$ \\
5 & $\mathrm{~GB}$ & $-20 / \mathrm{RT}$ & $15 \mathrm{~h}^{b}$ \\
6 & $\mathrm{~GB}$ & $-20 / \mathrm{RT}$ & $15 \mathrm{~h}^{b}$ \\
7 & $\mathrm{~GB}$ & $-20 / 35$ & $12 \mathrm{~h}^{b}$ \\
8 & $\mathrm{~GB}$ & $-20 / 35$ & $12 \mathrm{~h}^{b}$ \\
9 & $\mathrm{~GB}$ & $-20 / 5 / \mathrm{RT}$ & $12 \mathrm{~h}^{b, c}$ \\
10 & $\mathrm{~GB}$ & $-20 / 5 / \mathrm{RT}$ & $12 \mathrm{~h}^{b, c}$ \\
11 & $\mathrm{~GB}$ & $-20 / 5 / 35$ & $12 \mathrm{~h}^{b, c}$ \\
12 & $\mathrm{~GB}$ & $-20 / 5 / 35$ & $12 \mathrm{~h}^{b, c}$ \\
13 & $\mathrm{C}$ & $5 / 13$ & $8 \mathrm{~h}^{b}$ \\
14 & $\mathrm{~T}$ & $5 / 13$ & $8 \mathrm{~h}^{b}$ \\
15 & $\mathrm{GT}-\mathrm{A}$ & $5 / 13$ & $8 \mathrm{~h}^{b}$ \\
16 & $\mathrm{GT}-\mathrm{B}$ & $5 / 13$ & $8 \mathrm{~h}^{b}$ \\
17 & $\mathrm{C}$ & $5 / 13 / 21 / 30$ & $10 \mathrm{~h}^{d}$ \\
18 & $\mathrm{~T}$ & $5 / 13 / 21 / 30$ & $10 \mathrm{~h}^{d}$ \\
19 & $\mathrm{GT}-\mathrm{A}$ & $5 / 13 / 21 / 30$ & $10 \mathrm{~h}^{d}$ \\
20 & $\mathrm{GT}-\mathrm{B}$ & $5 / 13 / 21 / 30$ & $10 \mathrm{~h}^{d}$ \\
\hline
\end{tabular}

${ }^{a} \mathrm{RT}$, room temperature $\left(\sim 21^{\circ} \mathrm{C}\right)$.

${ }^{b}$ Holding time at RT, $13^{\circ} \mathrm{C}$, or $35^{\circ} \mathrm{C}$. Initial sampling occurred on inoculation (for nonfrozen coarse-ground beef samples), when inoculated poultry products were moved to $13^{\circ} \mathrm{C}$ storage, or when frozen coarse-ground beef was removed from the freezer.

${ }^{c}$ Sampling was done when the center of the meat mass reached $5^{\circ} \mathrm{C}$ and perodically during storage at RT or $35^{\circ} \mathrm{C}$.

${ }^{d}$ The product was held at $13^{\circ} \mathrm{C}$ for $3 \mathrm{~h}, 21^{\circ} \mathrm{C}$ for $3 \mathrm{~h}$, and $30^{\circ} \mathrm{C}$ for $4 \mathrm{~h}$. Initial sampling was done when the product was moved to $13^{\circ} \mathrm{C}$ storage.

ature and provide data to enter into THERM. Data points were selected by dividing the experiment time into 20 equal intervals and determining the temperature at each of the times from the data logger output. One sample of each product type was analyzed at 3,6 , and $8 \mathrm{~h}$ (experiments 13 to 16 ) or at 3,6 , and $10 \mathrm{~h}$ (experiments 17 to 20). Microbiological analyses were conducted as described earlier.

Statistical analyses. The paired $t$ test, with a 5\% significance level (release 12, Minitab, Inc., State College, Pa.), was done to compare the LPD and GR values for a given pathogen between products (ground pork, ground beef, and ground turkey) and for a given product between pathogens (E. coli O157:H7, Salmonella serovars, and $S$. aureus). In experiments to test THERM, each log CFU value obtained in an experiment was subtracted from its corresponding time zero value to obtain observed $\Delta \log$ CFU values. Time-temperature data from each experiment were entered into THERM to obtain predicted $\Delta \log$ CFU values. The observed $\Delta \log$ CFU values were compared with the predicted values by the paired $t$ test and regression analysis (Minitab).

\section{RESULTS AND DISCUSSION}

Earlier experiments in our laboratory showed that the level of indigenous microorganisms had a significant effect on the LPD values for $S$. aureus (data not shown) but not for $E$. coli $\mathrm{O} 157: \mathrm{H} 7$ or Salmonella serovars, with larger $S$. aureus LPD values resulting when there were greater numbers of indigenous organisms. Therefore, to develop a conservative predictive tool, all development experiments used meat products that had what we considered low levels of background organisms, i.e., $\leq 3.5 \mathrm{log} \mathrm{CFU} / \mathrm{g}$. This level was slightly lower than the mean APC values reported in USDA baseline surveys of ground beef, turkey, and chicken $(15,17,18)$. All ground meat used in developing THERM contained $<3.5 \log \mathrm{CFU} / \mathrm{g}$, as measured by a $35^{\circ} \mathrm{C}$ incubation temperature. Higher plate count values might have been obtained if an incubation temperature more suitable for the growth of psychrotrophic bacteria had been used, although the longer incubation time required for such an analysis discourages use of this analysis by meat processors and regulators.

By the DMFit 1.0 program, we were able to successfully determine LPD and GR values on the basis of a bestfit microbial growth curve produced by the software (Tables 3 through 5). For each curve, an $R^{2}$ value was calculated. The $R^{2}$ value is a number from 0 to 1 that represents the relative predictive power of the model. The closer the $R^{2}$ value is to 1 , the greater the model's accuracy. All $R^{2}$ values for ground pork were $\geq 0.73$, with $78 \%$ of the values $\geq 0.90$, and all $R^{2}$ values for ground beef were $\geq 0.70$, with $80 \%$ of the values $\geq 0.90$. For turkey, all $R^{2}$ values were $\geq 0.73$, with $62 \%$ of the values $\geq 0.90$. The only statistically significant $(P<0.05)$ differences in LPD or GR values were as follows: (i) LPD values for Salmonella serovars were lower in beef than in pork, (ii) LPD values for $S$. aureus were higher than for E. coli O157:H7 and Salmonella serovars in beef and higher than for E. coli O157:H7 in pork, and (iii) GR values for $S$. aureus were lower than for E. coli O157:H7 and Salmonella serovars in beef and turkey, respectively. As expected, LPD values decreased and GR values increased as the temperature increased to an optimum for growth. Although differences in experimental conditions preclude direct comparisons, the LPD value observed at $29.5^{\circ} \mathrm{C}$ for Salmonella serovars in ground turkey (Table 5) was similar to the reported LPD value determined for Salmonella Typhimurium on irradiated, raw, skinless chicken breast at $30^{\circ} \mathrm{C}$ (9). Similarly, the LPD values for Salmonella serovars in ground turkey (Table 5) were consistent with the LPD values reported for Salmonella Typhimurium on heat-sterilized ground chicken meat at temperatures ranging from 10 to $40^{\circ} \mathrm{C}(10)$. The LPD values for Salmonella serovars in ground beef (Table 4) were consistently lower than the derived lag times reported for Salmonella Typhimurium on irradiation-sterilized lean beef tissue (2).

The LPD and GR values for pathogen growth in raw, inoculated pork, beef, and turkey were used to develop THERM. The THERM tool can be used in situations for which a series of temperature measurements (of either the product or its storage environment) is available to enter into the program. The THERM user enters each temperature measurement and the corresponding time at which the temperature was measured. The THERM tool predicts the $\Delta \log \mathrm{CFU}$ for the pathogen of interest. 
TABLE 7. Observed and predicted (THERM) growth of Escherichia coli O157:H7 (EC), Salmonella serovars (SALM), and Staphylococcus aureus $(S A)$ in coarse-ground beef $(G B)$, skinless chicken breasts $(C)$, turkey scapula meat $(T)$, ground turkey from plant $A(G T$ $A)$, and ground turkey from plant $B(G T-B)$ during storage at abusive temperatures ${ }^{a}$

\begin{tabular}{|c|c|c|c|c|c|c|c|c|c|c|}
\hline \multirow{4}{*}{$\begin{array}{l}\text { Expt } \\
\text { no. }\end{array}$} & \multirow[b]{4}{*}{ Product } & & & \multirow{4}{*}{$\begin{array}{l}\text { Length of } \\
\text { trial (min) }\end{array}$} & \multicolumn{6}{|c|}{ Log CFU } \\
\hline & & \multirow{2}{*}{\multicolumn{2}{|c|}{$\begin{array}{c}\text { Measured } \mathrm{P} \text { or } \mathrm{Ch} \text {, } \\
\text { temp }\left({ }^{\circ} \mathrm{C}\right)\end{array}$}} & & \multicolumn{2}{|r|}{ EC } & \multicolumn{2}{|r|}{ SALM } & \multicolumn{2}{|r|}{ SA } \\
\hline & & & & & & End (observed/ & & End (observed/ & & End (observed/ \\
\hline & & Start & End & & Start & predicted) & Start & predicted) & Start & predicted) \\
\hline 1 & GB & $\mathrm{P}, 13.4$ & $\mathrm{P}, 19.0$ & 340 & 4.9 & $4.8 / 4.9$ & 4.7 & $4.3 / 4.8$ & 4.9 & $4.9 / 4.9$ \\
\hline 2 & GB & $\mathrm{P}, 16.4$ & P, 20.3 & 360 & 4.9 & $5.0 / 5.3$ & 4.5 & $4.6 / 5.0$ & 4.7 & $4.8 / 4.7$ \\
\hline 3 & GB & P, 22.0 & P, 28.6 & 180 & 4.9 & $5.0 / 5.2$ & 4.7 & $4.5 / 4.9$ & 4.8 & $4.7 / 4.8$ \\
\hline 4 & GB & P, 23.0 & P, 29.2 & 240 & 4.9 & $5.2 / 5.4$ & 4.4 & $5.0 / 4.9$ & 4.8 & $4.8 / 4.8$ \\
\hline 5 & GB & $P,-19.6$ & P, 20.1 & 900 & 5.0 & $4.9 / 5.7$ & 4.7 & $4.8 / 5.3$ & 4.6 & $4.7 / 4.6$ \\
\hline 6 & GB & $\mathrm{P},-19.2$ & P, 18.2 & 900 & 4.9 & $5.0 / 5.1$ & 4.6 & $4.7 / 4.6$ & 4.9 & $4.9 / 4.9$ \\
\hline 7 & GB & $\mathrm{P},-3.2$ & P, 29.8 & 720 & 4.8 & $5.7 / 5.8$ & 4.3 & $4.5 / 5.1$ & 4.5 & $4.5 / 4.6$ \\
\hline 8 & GB & $\mathrm{P},-1.4$ & P, 31.1 & 720 & 4.8 & $6.0 / 7.0$ & 4.3 & $4.9 / 6.3$ & 4.5 & $4.8 / 5.7$ \\
\hline 9 & GB & P, 8.3 & $\mathrm{P}, 17.1$ & 720 & 4.7 & $4.9 / 5.2$ & 4.5 & $4.8 / 4.8$ & 4.9 & $5.0 / 5.0$ \\
\hline 10 & GB & P, 3.3 & P, 16.8 & 720 & 4.8 & $5.3 / 5.5$ & 4.2 & $4.6 / 4.7$ & 4.8 & $4.9 / 5.1$ \\
\hline 11 & GB & P, 7.8 & P, 32.4 & 720 & 4.7 & $8.4 / 9.3$ & 4.2 & $8.2 / 8.2$ & 4.5 & 7.3/7.6 \\
\hline 12 & GB & P, 9.7 & P, 31.3 & 720 & 4.6 & 8.3/8.2 & 4.1 & $8.0 / 7.4$ & 4.6 & $5.9 / 7.2$ \\
\hline 13 & $\mathrm{C}$ & $\mathrm{Ch}, 5$ & Ch, 13 & 480 & NT & NT & 4.5 & $4.6 / 4.5$ & 4.9 & $4.9 / 4.9$ \\
\hline 17 & $\mathrm{C}$ & $\mathrm{Ch}, 5$ & $\mathrm{Ch}, 30$ & 600 & NT & NT & 4.8 & $6.4 / 6.7$ & 3.7 & $5.5 / 4.3$ \\
\hline 14 & $\mathrm{~T}$ & $\mathrm{Ch}, 5$ & Ch, 13 & 480 & NT & NT & 4.5 & $4.4 / 4.5$ & 4.9 & $4.9 / 4.9$ \\
\hline 18 & $\mathrm{~T}$ & $\mathrm{Ch}, 5$ & $\mathrm{Ch}, 30$ & 600 & NT & NT & 4.8 & $6.5 / 6.7$ & 3.4 & $5.5 / 4.0$ \\
\hline 15 & GT-A & $\mathrm{Ch}, 5$ & Ch, 13 & 480 & NT & NT & 4.6 & $4.5 / 4.6$ & 4.9 & $4.9 / 4.9$ \\
\hline 19 & GT-A & $\mathrm{Ch}, 5$ & $\mathrm{Ch}, 30$ & 600 & NT & NT & 4.9 & $6.4 / 6.8$ & 4.0 & $5.4 / 4.6$ \\
\hline 16 & GT-B & $\mathrm{Ch}, 5$ & Ch, 13 & 480 & NT & NT & 4.5 & $4.5 / 4.5$ & 4.9 & $4.9 / 4.9$ \\
\hline 20 & GT-B & $\mathrm{Ch}, 5$ & $\mathrm{Ch}, 30$ & 600 & NT & NT & 4.9 & $6.5 / 6.8$ & 3.7 & $5.6 / 4.3$ \\
\hline
\end{tabular}

${ }^{a}$ Each $\log$ CFU value represents either the log CFU for a single 25-g sample of coarse-ground beef or ground turkey or the mean log CFU per gram $(n=2)$ for chicken breast or turkey scapula meat samples. P, product; Ch, chamber; NT, not tested.

The results of the experiments that were used to test THERM are shown in Table 7. The greatest observed $\Delta \log$ CFU value was 4.0 for Salmonella serovars in experiment 11 coarse-ground beef, while the greatest predicted $\Delta \log$ CFU value was 4.6 for E. coli $\mathrm{O} 157: \mathrm{H} 7$ in the same experiment. We first qualitatively evaluated the predicted and observed $\Delta \log$ CFU values, i.e., described predictions and observations as either "growth" or "no growth." We used the criteria of growth $=\Delta \log$ CFU $>$ 0.3 (more than one doubling) and no growth = $\Delta \log \mathrm{CFU} \leq 0.3$ (see Table 8). According to these criteria, E. coli $\mathrm{O} 157: \mathrm{H} 7$ grew in experiments $7,8,11$, and 12 (coarse-ground beef at $35^{\circ} \mathrm{C}$ storage) and in experiment 10 (coarse-ground beef at RT storage). Salmonella serovars grew in coarse-ground beef in experiments $4,8,11$, and 12 (all of which involved $35^{\circ} \mathrm{C}$ storage) and in experiment 10 (coarse-ground beef at RT storage), as well as in all of the poultry experiments that involved $30^{\circ} \mathrm{C}$ storage (experiments 17 to 20). S. aureus grew in experiments 11 and 12 (coarse-ground beef stored at $35^{\circ} \mathrm{C}$ ) and on all of the poultry products stored at $30^{\circ} \mathrm{C}$ (experiments 17 to 20). The THERM tool accurately predicted whether growth would occur in 67,85 , and $95 \%$ of the experiments that involved E. coli O157, Salmonella serovars, and S. aureus, respectively (Table 8 ). In all other experiments, THERM predicted pathogen growth when it was not observed experimentally, i.e., made a "fail-safe" prediction. Notably, THERM never made a "fail-dangerous" prediction, i.e., never failed to predict growth when it was observed experimentally.

The THERM tool did not perform as well when we made quantitative comparisons, i.e., direct comparisons of predicted and observed $\Delta \log$ CFU values (see Table 9). In this type of evaluation, we considered a predicted $\Delta \log$ CFU value accurate if it was within 0.3 of the observed value (within one doubling). In coarse-ground beef experiments, THERM predictions were accurate in 67, 42, and $83 \%$ of the experiments with E. coli O157, Salmonella serovars, and $S$. aureus, respectively. All the remaining (not "accurate") THERM predictions for coarse-ground beef experiments were fail-safe (the predicted $\Delta \log$ CFU value exceeded the observed $\Delta \log$ CFU value by more than 0.3 ), with the exception of a fail-dangerous prediction for the growth of Salmonella serovars in experiment 12.

Notably different results were obtained in the poultry product experiments. The THERM tool performed well in predicting the growth of Salmonella serovars (88\% accurate, $12 \%$ fail-safe; Table 9) but yielded fail-dangerous predictions for $S$. aureus in $50 \%$ of the experiments. The observed growth of $S$. aureus in the poultry product experiments exceeded the fail-safe predicted levels by 0.8 to 1.5 $\log$ CFU. This underpredicted growth would have the most adverse consequences if the initial populations of $S$. aureus were such that the predicted growth would not result in enough enterotoxin production to cause illness but the ob- 
TABLE 8. Qualitative accuracy of predictions (THERM) for predicting growth or no growth of Escherichia coli O157:H7 (EC), Salmonella serovars (SALM), and Staphylococcus aureus (SA) in coarse-ground beef (GB), skinless chicken breasts (C), turkey scapula meat $(T)$, ground turkey from plant $A(G T-A)$, and ground turkey from plant B $(G T-B)$ during storage at abusive temperatures ${ }^{a}$

\begin{tabular}{|c|c|c|c|c|c|c|c|c|c|c|}
\hline \multirow{2}{*}{$\begin{array}{c}\text { Expt } \\
\text { no. }\end{array}$} & \multirow[b]{2}{*}{ Product } & \multicolumn{3}{|c|}{ EC growth $>0.3 \log \mathrm{CFU}$} & \multicolumn{3}{|c|}{ SALM growth $>0.3 \log$ CFU } & \multicolumn{3}{|c|}{ SA growth $>0.3 \log \mathrm{CFU}$} \\
\hline & & Observed & Predicted & Accuracy & Observed & Predicted & Accuracy & Observed & Predicted & Accuracy \\
\hline 1 & GB & - & - & Acc & - & - & Acc & - & - & Acc \\
\hline 2 & GB & - & + & F-S & - & + & F-S & - & - & Acc \\
\hline 3 & GB & - & - & Acc & - & - & Acc & - & - & Acc \\
\hline 4 & GB & - & + & $\mathrm{F}-\mathrm{S}$ & + & + & Acc & - & - & Acc \\
\hline 5 & GB & - & + & $\mathrm{F}-\mathrm{S}$ & - & + & $\mathrm{F}-\mathrm{S}$ & - & - & Acc \\
\hline 6 & GB & - & - & Acc & - & - & Acc & - & - & Acc \\
\hline 7 & GB & + & + & Acc & - & + & F-S & - & - & Acc \\
\hline 8 & GB & + & + & Acc & + & + & Acc & - & + & F-S \\
\hline 9 & GB & - & + & F-S & - & - & Acc & - & - & Acc \\
\hline 10 & GB & + & + & Acc & + & + & Acc & - & - & Acc \\
\hline 11 & GB & + & + & Acc & + & + & Acc & + & + & Acc \\
\hline 12 & GB & + & + & Acc & + & + & Acc & + & + & Acc \\
\hline Total & GB & & & $\begin{array}{l}67 \% \text { Acc } \\
33 \% \text { F-S }\end{array}$ & & & $\begin{array}{l}75 \% \text { Acc } \\
25 \% \text { F-S }\end{array}$ & & & $\begin{array}{c}91 \% \text { Acc } \\
9 \% \text { F-S }\end{array}$ \\
\hline 13 & $\mathrm{C}$ & NT & NT & NT & - & - & Acc & - & - & Acc \\
\hline 17 & $\mathrm{C}$ & NT & NT & NT & + & + & Acc & + & + & Acc \\
\hline 14 & $\mathrm{~T}$ & NT & NT & NT & - & - & Acc & - & - & Acc \\
\hline 18 & $\mathrm{~T}$ & NT & NT & NT & + & + & Acc & + & + & Acc \\
\hline 15 & GT-A & NT & NT & NT & - & - & Acc & - & - & Acc \\
\hline 19 & GT-A & NT & NT & NT & + & + & Acc & + & + & Acc \\
\hline 16 & GT-B & NT & NT & NT & - & - & Acc & - & - & Acc \\
\hline 20 & GT-B & NT & NT & NT & + & + & Acc & + & + & Acc \\
\hline Total & Poultry & & & & & & $100 \%$ Acc & & & $100 \%$ Acc \\
\hline Total $^{b}$ & & & & $67 \%$ Acc & & & $85 \%$ Acc & & & $95 \%$ Acc \\
\hline & & & & $33 \% \mathrm{~F}-\mathrm{S}$ & & & $15 \%$ F-S & & & $5 \% \mathrm{~F}-\mathrm{S}$ \\
\hline
\end{tabular}

${ }^{a}$ Growth $=$ increase of $>0.3 \log$ CFU; no growth $=$ increase of $\leq 0.3 \log$ CFU. - , no; Acc, accurate; +, yes; F-S, fail-safe, i.e., predicted growth was $>0.3 \log \mathrm{CFU}$, and observed growth was $\leq 0.3 \log \mathrm{CFU}$; NT, not tested.

${ }^{b}$ Denotes overall total.

served growth would. The major compositional differences between the laboratory-ground turkey meat used in developing THERM and the commercial poultry products used in testing THERM are that the commercial products all contained more fat, and the commercial ground turkey contained more salt. It is possible that these differences inhibited competing microorganisms somewhat and allowed greater $S$. aureus growth than predicted by THERM.

In addition to comparing the predicted and observed $\Delta \log$ CFU values for each pathogen in each individual experiment, the paired $t$ test was used to compare predicted and observed $\Delta \log$ CFU values for each pathogen for all experiments combined. This analysis showed that predicted $\Delta \log$ CFU values were significantly higher than observed $\Delta \log$ CFU values for $E$. coli O157:H7 $(P=0.007)$ and Salmonella serovars $(P=0.02)$. The $R^{2}$ values from regression analysis were 0.94 and 0.89 , respectively, for these two pathogens, indicating a very consistent relationship between predicted and observed values. The $R^{2}$ value for $S$. aureus was only 0.43 , reflecting the divergence of predicted and observed values in poultry product experiments 17 to 20 . The paired $t$ test analysis did not show any statistically significant difference between predicted and observed values for $S$. aureus for all experiments combined $(P=0.49)$, perhaps reflecting the inconsistent relationship between predicted and observed results.

An additional way of testing the accuracy of THERM is to compare its pathogen growth predictions with the experimental pathogen growth observed in experiments in other laboratories. For example, a recent study by Mann and Brashears (7) suggested a critical limit for ground beef processors of "time in the processing area of $\leq 6 \mathrm{~h}$," with the processing area temperature defined as 22 to $23^{\circ} \mathrm{C}$. For $22.5^{\circ} \mathrm{C}$ storage of ground beef for $6 \mathrm{~h}$, with no additional warm-up or cool-down times (the same conditions as in Mann and Brashears (7)), the THERM tool predicted an increase for $E$. coli $\mathrm{O} 157: \mathrm{H} 7$ of $0.54 \log$ CFU. The experimentally determined $\Delta \log$ CFU value was 0.49 , indicating good agreement between THERM and the inoculation study. With a longer RT incubation, Mann and Brashears observed $\Delta \log$ CFU values (rounded) of 1.0, 1.4, and 1.8 for $E$. coli $\mathrm{O} 157: \mathrm{H} 7$ stored for 8, 10, and $12 \mathrm{~h}$, respectively. The corresponding $\Delta \log$ CFU values predicted by THERM for these times were $0.9,1.3$, and 1.7. For ground beef stored at $10^{\circ} \mathrm{C}$, Mann and Brashears observed $\Delta \log \mathrm{CFU}$ values of approximately $0.1,0.1,0.2,0.4,0.8$, and 1.0 at $4,8,12,24,48$, and $72 \mathrm{~h}$, respectively. The THERM tool predicted no growth of E. coli O157:H7 through 27 h, with 
TABLE 9. Quantitative accuracy of predictions (THERM) for predicting change in log CFU for Escherichia coli O157:H7 (EC), Salmonella serovars (SALM), and Staphylococcus aureus (SA) in coarse-ground beef $(G B)$, skinless chicken breasts $(C)$, turkey scapula meat $(T)$, ground turkey from plant $A(G T-A)$, and ground turkey from plant B $(G T-B)$ during storage at abusive temperatures ${ }^{a}$

\begin{tabular}{|c|c|c|c|c|c|c|c|c|c|c|}
\hline \multirow{2}{*}{$\begin{array}{c}\text { Expt } \\
\text { no. }\end{array}$} & \multirow[b]{2}{*}{ Product } & \multicolumn{3}{|c|}{ EC change in log CFU } & \multicolumn{3}{|c|}{ SALM change in log CFU } & \multicolumn{3}{|c|}{ SA change in log CFU } \\
\hline & & Observed & Predicted & Accuracy & Observed & Predicted & Accuracy & Observed & Predicted & Accuracy \\
\hline 1 & GB & -0.1 & 0 & Acc & -0.4 & 0.1 & $\mathrm{~F}-\mathrm{S}$ & 0 & 0 & Acc \\
\hline 2 & GB & 0.1 & 0.4 & Acc & 0.1 & 0.5 & $\mathrm{~F}-\mathrm{S}$ & 0.1 & 0 & Acc \\
\hline 3 & GB & 0.1 & 0.3 & Acc & -0.2 & 0.2 & F-S & -0.1 & 0 & Acc \\
\hline 4 & GB & 0.3 & 0.5 & Acc & 0.6 & 0.5 & Acc & 0 & 0 & Acc \\
\hline 5 & GB & -0.1 & 0.7 & $\mathrm{~F}-\mathrm{S}$ & 0.1 & 0.6 & $\mathrm{~F}-\mathrm{S}$ & 0.1 & 0 & Acc \\
\hline 6 & GB & 0.1 & 0.2 & Acc & 0.1 & 0 & Acc & 0 & 0 & Acc \\
\hline 7 & GB & 0.9 & 1.0 & Acc & 0.2 & 0.8 & F-S & 0 & 0.1 & Acc \\
\hline 8 & GB & 1.2 & 2.2 & F-S & 0.6 & 2.0 & F-S & 0.3 & 1.2 & F-S \\
\hline 9 & GB & 0.2 & 0.5 & F-S & 0.3 & 0.3 & Acc & 0.1 & 0.1 & Acc \\
\hline 10 & GB & 0.5 & 0.7 & Acc & 0.4 & 0.5 & Acc & 0.1 & 0.3 & Acc \\
\hline 11 & GB & 3.7 & 4.6 & F-S & 4.0 & 4.0 & Acc & 2.8 & 3.1 & Acc \\
\hline 12 & GB & 3.7 & 3.6 & Acc & 3.9 & 3.3 & F-D & 1.3 & 2.6 & F-S \\
\hline Total & GB & & & $\begin{array}{l}67 \% \text { Acc } \\
33 \% \text { F-S }\end{array}$ & & & $\begin{array}{c}42 \% \text { Acc } \\
49 \% \text { F-S } \\
9 \% \text { F-D }\end{array}$ & & & $\begin{array}{l}83 \% \text { Acc } \\
17 \% \text { F-S }\end{array}$ \\
\hline 13 & $\mathrm{C}$ & NT & NT & NT & 0.1 & 0 & Acc & 0 & 0 & Acc \\
\hline 17 & $\mathrm{C}$ & NT & NT & NT & 1.6 & 1.9 & Acc & 1.8 & 0.6 & F-D \\
\hline 14 & $\mathrm{~T}$ & NT & NT & NT & -0.1 & 0 & Acc & 0 & 0 & Acc \\
\hline 18 & $\mathrm{~T}$ & NT & NT & NT & 1.7 & 1.9 & Acc & 2.1 & 0.6 & F-D \\
\hline 15 & GT-A & NT & NT & NT & -0.1 & 0 & Acc & 0 & 0 & Acc \\
\hline 19 & GT-A & NT & NT & NT & 1.5 & 1.9 & F-S & 1.4 & 0.6 & F-D \\
\hline 16 & GT-B & NT & NT & NT & 0 & 0 & Acc & 0 & 0 & Acc \\
\hline 20 & GT-B & NT & NT & NT & 1.6 & 1.9 & Acc & 1.9 & 0.6 & F-D \\
\hline Total & Poultry & & & & & & $\begin{array}{l}88 \% \text { Acc } \\
12 \% \text { F-S }\end{array}$ & & & $\begin{array}{ll}50 \% & \text { Acc } \\
50 \% & \text { F-D }\end{array}$ \\
\hline Total $^{b}$ & & & & $\begin{array}{l}67 \% \text { Acc } \\
33 \% \text { F-S }\end{array}$ & & & $\begin{array}{c}60 \% \text { Acc } \\
35 \% \text { F-S } \\
5 \% \text { F-D }\end{array}$ & & & $\begin{array}{l}70 \% \text { Acc } \\
10 \% \text { F-S } \\
20 \% \text { F-D }\end{array}$ \\
\hline
\end{tabular}

${ }^{a}$ Acc, accurate; observed and predicted growth differed by $<0.3 \log \mathrm{CFU}$; F-S, fail-safe, i.e., predicted growth was at least 0.3 log CFU greater than observed growth; F-D, fail-dangerous, i.e., predicted growth was at least 0.3 log CFU less than observed growth; NT, not tested.

${ }^{b}$ Denotes overall total.

$\Delta \log$ CFU values of 0.5 at $48 \mathrm{~h}$ and 1.1 at $72 \mathrm{~h}$. By the qualitative approach discussed earlier, we conclude that the THERM tool predictions are consistent with those from the Mann and Brashears study.

From our results, we conclude that the THERM tool is useful for qualitatively predicting the growth of all three pathogens in raw meats in general and for quantitatively predicting the growth of all three pathogens in raw beef and Salmonella serovars on raw poultry. The THERM tool appears to be less useful for the quantitative prediction of $S$. aureus growth on raw poultry. There are several potential shortcomings to THERM that may adversely affect its performance. First, the use of multistrain cocktails in developing THERM means that the fastest growing strain has the greatest effect on the calculated lag time and GR (22). However, the presence of an unusually rapid-growing strain (or strains) would increase the conservative nature of the THERM tool by resulting in smaller LPD or larger GR values and thereby decrease the likelihood that THERM would underestimate pathogen growth. Second, THERM does not account for a variety of inhibitory ingredients, e.g., fat, sodium chloride, sodium nitrite, liquid smoke, inhibitory processing condi- tions (e.g., dry-curing, cold-smoking, drying), to which pathogens or competing microorganisms may be exposed during the temperature abuse of raw meat products. Additional versions of THERM could be developed, however, for use with products that have a different composition from that of the ground meats we used in this study. Other researchers have attempted to account for inhibitors of microbial growth and have modeled the temperature, $\mathrm{pH}$, and water activity conditions at the growth-no growth boundary for Salmonella Typhimurium in broth (6). However, to our knowledge, analogous studies with meat systems have not been published. Third, THERM was developed with ground meats rather than intact muscle tissue. Mann et al. (8) have shown that the growth of Salmonella is faster in ground pork than in whole-muscle pork. This trend was not seen when we compared the predicted $\Delta \log$ CFU values (from ground turkey) with the observed $\Delta \log$ CFU values from unground poultry products. Fourth, some pathogen strains may be capable of growth at temperatures slightly above or below the limits of THERM (11), although the ability of hemorrhagic E. coli to grow at $8^{\circ} \mathrm{C}$ in ground beef has been reported to decrease when high levels of background organisms are present (12). 
Growth at temperatures below the THERM lower limits would likely have little effect on the accuracy of THERM predictions because of the long LPD values expected at such low temperatures, but THERM growth predictions could be erroneously low if growth occurred at temperatures above the $43.3^{\circ} \mathrm{C}$ upper limit of THERM. The level of background organisms in the ground meats used to develop THERM was always considerably lower than the level of inoculum organisms, which could add to the conservative performance of THERM. Competition from background organisms has been shown to slow the growth of E. coli $\mathrm{O} 157: \mathrm{H} 7$ in ground beef (21) and laboratory broth (3) and of $S$. aureus on minced turkey (23). Our preliminary experiments, done to develop inoculum preparation techniques, also showed this trend. Finally, it is possible that pathogens that originate from the hide or skin or the intestinal tract of an animal are in a physiological state better suited to rapid growth in meat than are pathogens grown in laboratory medium. This possibility should be investigated in future studies.

Overall, the THERM tool was accurate or fail-safe in qualitatively predicting whether E. coli O157:H7, Salmonella serovars, and $S$. aureus grew in raw beef and on poultry products during experiments designed to test the tool's performance. Therefore, this tool would be useful for processors who evaluate the potential critical limits associated with raw meat processing CCPs. Critical limits could be evaluated by entering possible time-temperature combinations into THERM to see if pathogen growth is predicted. For example, a processor could propose a critical limit for preventing Salmonella growth during raw pork processing as follows: "during processing, the product shall not be at temperatures of 5 to $15.6^{\circ} \mathrm{C}$ for more than $2 \mathrm{~h}$ and then shall be cooled to below $5^{\circ} \mathrm{C}$ within another $2 \mathrm{~h}$." A conservative approach would then be to enter time-temperature pairs representing immediate warm-up to $15.6^{\circ} \mathrm{C}$, holding at $15.6^{\circ} \mathrm{C}$ for $4 \mathrm{~h}$, and immediate cool-down. With this information entered, THERM would predict no growth of Salmonella serovars, as the LPD at $15.6^{\circ} \mathrm{C}$ is much greater than $4 \mathrm{~h}$ (490 min; see Table 3). Alternatively, time-temperature data from several lots of a product that meet the proposed critical limit could be entered into THERM to determine if pathogen growth is predicted. The THERM tool could also be used to evaluate product safety in a situation in which critical limits are not met, i.e., a deviation.

On the basis of the results of our study, we recommend the qualitative use of THERM by processors for developing critical limits or evaluating deviations that involve the temperature abuse of raw ground pork, beef, and poultry products. Processors may download THERM from www.wisc. edu/foodsafety/meatresearch.

\section{ACKNOWLEDGMENTS}

This study was financially supported by a grant from the USDA, Cooperative State Research, Education, and Extension Service, National Integrated Food Safety Initiative. We are indebted to the following undergraduate students for their laboratory assistance: Ryan Algino, Amy Haen, Julia Heinrich, Andrew Jensen, Erica Schoeller, and Melissa Talbot. In addition, we thank Justin Kral for authoring the THERM-web interface and designing the Website for THERM.

\section{REFERENCES}

1. Burnham, G. M., M. A. Fanslau, and S. C. Ingham. 2006. Evaluating microbial safety of slow partial-cooking processes for bacon: use of a predictive tool based on small-scale isothermal meat inoculation studies. J. Food Prot. 69:602-608.

2. Dickson, J. S., G. R. Siragusa, and J. E. Wray, Jr. 1992. Predicting the growth of Salmonella typhimurium on beef by using the temperature function integration technique. Appl. Environ. Microbiol. 58:3482-3487.

3. Duffy, G., R. C. Whiting, and J. J. Sheridan. 1999. The effect of a competitive microflora, $\mathrm{pH}$ and temperature on the growth kinetics of Escherichia coli O157:H7. Food Microbiol. 16:299-307.

4. Ingham, S. C., J. A. Losinski, K. L. Becker, and D. R. Buege. 2004. Growth of Escherichia coli O157:H7 and Salmonella serovars on raw beef, pork, chicken, bratwurst and cured corned beef: implication for HACCP plan critical limits. J. Food Saf. 24:246-256.

5. Ingham, S. C., R. K. Wadhera, M. A. Fanslau, and D. R. Buege. 2005. Growth of Salmonella serovars, Escherichia coli O157:H7, and Staphylococcus aureus during thawing of whole chicken and retail ground beef portions at 22 and $30^{\circ} \mathrm{C}$. J. Food Prot. 68:1457-1461.

6. Koutsoumanis, K. P., P. M. Kendall, and J. N. Sofos. 2004. Modeling the boundaries of growth of Salmonella Typhimurium in broth as a function of temperature, water activity, and pH. J. Food Prot. 67: $\underline{53-59 .}$

7. Mann, J. E., and M. M. Brashears. 2006. Validation of time and temperature values as critical limits for the control of Escherichia coli O157:H7 during the production of fresh ground beef. $\underline{\text { J. Food }}$ Prot. 69:1978-1982.

8. Mann, J. E., L. Smith, and M. M. Brashears. 2004. Validation of time and temperature values as critical limits for Salmonella and background flora growth during the production of fresh ground and boneless pork products. J. Food Prot. 67:1389-1393.

9. McKay, A. L., A. C. Peters, and A. C. Hann. 1997. The growth of Salmonella typhimurium on irradiated, raw, skinless chicken breast. Int. J. Food Microbiol. 37:121-129.

10. Oscar, T. P. 2005. Development and validation of primary, secondary, and tertiary models for growth of Salmonella Typhimurium on sterile chicken. J. Food Prot. 68:2606-2613.

11. Palumbo, S. A., J. E. Call, F. J. Schultz, and A. C. Williams. 1995. Minimum and maximum temperatures for growth and verotoxin production by hemorrhagic strains of Escherichia coli. J. Food Prot. 58:352-356.

12. Palumbo, S. A., A. Pickard, and J. E. Call. 1997. Population changes and verotoxin production of enterohemorrhagic Escherichia coli strains inoculated in milk and ground beef held at low temperatures. J. Food Prot. 60:746-750.

13. Tamplin, M. L. 2002. Growth of Escherichia coli O157:H7 in raw ground beef stored at $10^{\circ} \mathrm{C}$ and the influence of competitive bacterial flora, strain variation, and fat level. J. Food Prot. 65:1535-1540.

14. Tamplin, M. L., G. Paoli, B. S. Marmer, and J. Phillips. 2005. Models of the behavior of Escherichia coli $\mathrm{O} 157: \mathrm{H} 7$ in raw sterile ground beef stored at 5 to $46^{\circ}$ C. Int. J. Food Microbiol. 100:335-344.

15. U.S. Department of Agriculture, Food Safety and Inspection Service. 1994. Nationwide federal plant raw ground beef microbiological survey. Available at: http://www.fsis.usda.gov/OPHS/baseline/rwgrbeef. pdf. Accessed 26 May 2006.

16. U.S. Department of Agriculture, Food Safety and Inspection Service. 1996. Pathogen reduction; hazard analysis and critical control point (HACCP) systems: final rule. Fed. Regist. 61:38805-38989.

17. U.S. Department of Agriculture, Food Safety and Inspection Service. 1996. Nationwide raw ground turkey microbiological survey. Available at: http://www.fsis.usda.gov/OPHS/baseline/rwgrturk.pdf. Accessed 26 May 2006.

18. U.S. Department of Agriculture, Food Safety and Inspection Service. 1996. Nationwide raw ground chicken microbiological survey. Available at: http://www.fsis.usda.gov/OPHS/baseline/rwgrchck.pdf. Accessed 26 May 2006. 
19. U.S. Department of Agriculture, Food Safety and Inspection Service. 2003. Poultry products inspection regulations-temperatures and chilling and freezing procedures. 9 CFR 381.66. U.S. Government Printing Office, Washington, D.C.

20. U.S. Department of Agriculture, Food Safety and Inspection Service. 2005. Use of microbial pathogen computer modeling in HACCP plans, FSIS notice 25-05. Available at: http://www.fsis.usda.gov/ regulations/notice_25-05/default.asp. Accessed 18 May 2006.

21. Vold, L., A. Holck, Y. Wasteson, and H. Nissen. 2000. High levels of background flora inhibit growth of Escherichia coli $\mathrm{O} 157: \mathrm{H7}$ in ground beef. Int. J. Food Microbiol. 56:219-225.

22. Whiting, R. C., and M. H. Golden. 2002. Variation among Escherichia coli $\mathrm{O} 157: \mathrm{H} 7$ strains relative to their growth, survival, thermal inactivation, and toxin production in broth. Int. J. Food Microbiol. 75:127-133.

23. Yang, X., R. G. Board, and G. C. Mead. 1988. Influence of spoilage flora and temperature on growth of Staphylococcus aureus in turkey meat. J. Food Prot. 51:303-309. 